\title{
SODIUM BALANCE IN ADULT ATLANTIC SALMON (SALMO SALAR L.) DURING MIGRATION INTO NEUTRAL AND ACID FRESH WATER
}

\author{
W. T. W. Potts, * C. Talbot $\nmid \nmid$ F. B. Eddy $\ddagger$ D. Primmett,$\S$ P. Prunett $\|$ and M. Williams $\dagger$ \\ *Department of Biological Sciences, University of Lancaster, Lancaster LA1 4YQ, U.K. Telephone:

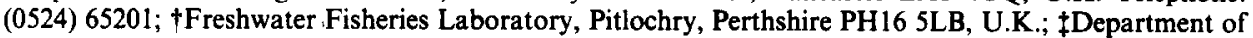 \\ Biological Sciences, University of Dundee, Dundee DD1 4HN, U.K.; §Department of Human Anatomy, \\ University of Oxford, Oxford OX1 3QX, U.K.; and \|Laboratoire de Physiologie des Poissons, INRA \\ Campus de Beaulieu, 35042 Rennes Cedex, France
}

(Received 28 July 1988)

\begin{abstract}
In sea-water, adult salmon ( $S$. salar) exchange an average of $12.6 \%$ of total body sodium/hr.
2. Following transfer to fresh water sodium uptake follows Michaelis-Menton kinetics. $F_{\max }=2.40 \mathrm{mmol} \mathrm{Na} / 1 \mathrm{ECF} / \mathrm{hr}, K_{\mathrm{m}}=0.26 \mathrm{mmol} \mathrm{Na} / \mathrm{l}$. The uptake system is fully activated immediately following transfer to fresh water.

3. Post smolts adapted to sea-water for 3 months take up sodium at only one third of the rate of adult fish following return to fresh water.

4. The concentration of prolactin in the plasma is low in sea-water adapted fish and does not rise during the first $8 \mathrm{hr}$ in fresh water.

5. At pH 5 sodium uptake is reduced by almost $90 \%$, even in the absence of aluminium, but recovers immediately on return to neutral water.

6. At pH 5 and $20 \mu \mathrm{mol} \mathrm{Al} / \mathrm{l}$ there is little further effect on sodium uptake but after $6 \mathrm{hr}$ in aluminium the inhibition of sodium uptake continues after return to neutral aluminium fresh water and uptake is only $50 \%$ of normal $24 \mathrm{hr}$ later.
\end{abstract}

\section{INTRODUCTION}

Little work has been carried out on salt and water balance in the adult Atlantic salmon, Salmo salar, in contrast to many papers on the physiology of its eggs, parr and smolts. The physiology of migration from sea-water to fresh water is of both of fundamental and practical importance. The processes of adaptation from hypo-osmotic regulation in sea-water to hyperosmotic regulation in fresh water involve rapid adaptations of the gills, kidneys and endocrine systems, about which little is known. From the practical point of view these changes may affect the time spent by homing salmon in estuaries, where in Britain they are vulnerable to netting. During migration from sea-water to fresh water the salmon is subject to severe physiological stresses even when the water is neutral, while the evidence available suggests that the Atlantic salmon is more susceptible to acid waters than is the brown trout, $S$. turtta or the American brook trout $S$. salvelinus.

Kills of migrating salmon have been reported on several occasions in the rivers Esk and Duddon in Cumberland and the continuous monitoring programme instituted by the NWWA on these rivers (Crawshaw, 1984) has provided contemporary data on river flow and $\mathrm{pH}$. During a fish kill in the rivers Esk and Duddon in 1983 the pH of the Esk at Cropple How twice fell to $\mathrm{pH} 4.5$ during two spates on September 16th and 18th and remained below pH 5.0 for about $8 \mathrm{hr}$ on each occasion (Crawshaw, 1984, Fig. 1).
Contemporary analyses of aluminium are not available but the correlation between water chemistry and $\mathrm{pH}$ on the Esk is very high. Crawshaw 1984. A $\mathrm{pH}$ of 5.0 corresponds to about $250 \mu \mathrm{g} \mathrm{Al} / \mathrm{l}, \mathrm{ca}$ $10 \mu \mathrm{mol} / \mathrm{l}$ in the river Esk. At the peak of acidity the Al might have reached $20 \mu \mathrm{mol} / \mathrm{l}$.

\section{MATERIALS AND METHODS}

Adult salmon, Salmo salar L., were obtained from coastal nets in sea-water at Carnoustie, Angus. These were maintained in the DAFS laboratory at Almondbank, Perth, in a tank of recirculated, filtered and deproteinized sea-water of $29 \%$ salinity, at $12^{\circ} \mathrm{C}$. A few salmon were caught in tidal fresh water in the Tay estuary at Inchyra, $2 \mathrm{~km}$ south of Perth. Some of these fish, which still had "sea lice" on their bodies were transferred to sea water for at least 5 days before use, while others were transferred to running fresh water from the river Almond. Some experiments were carried out with large $4+$ parr, ca $300-500 \mathrm{~g}$, reared in Almond river water and with post-smolts which had been adapted to sea-water for 3 months.

Salmon were prepared with an indwelling catheter in the dorsal aorta, Smith and Bell (1964). Blood samples were taken from the large parr by caudal puncture after the fish had been killed by a blow on the head. Net sodium flux in fresh water was determined from the rate of change of the sodium content of the experimental tank and sodium efflux was calculated from the sum of the net flux and the influx. Fresh water experiments were carried out, as far as possible, in running water from the River Almond. In all closed circulation experiments the water was circulated round the tank by a rotary pump, $41 / \mathrm{min}$, so that therc was a flow of 


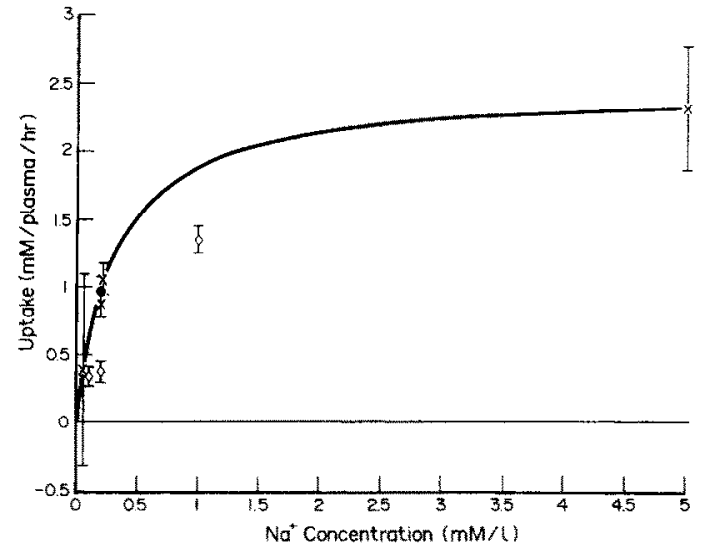

Fig. 1. Sodium uptake in adult salmon and in postsmolts adapted to sea-water following return to fresh water. $\times$ Adult salmon; $\diamond$ post-smolts immediately following return to fresh water; Post-smolts after $42 \mathrm{hr}$ in fresh water.

$$
\text { Uptake }=2.40\left(\frac{C}{C+0.26}\right)
$$

water from head to tail of the fish. When the experiment was prolonged the water was pumped through a carbon filter.

Sodium influxes were measured by adding $10-40 \mu \mathrm{C}$ of ${ }^{24} \mathrm{Na}$ to the tank and taking a blood sample after a suitable period of time, generally 1 or $2 \mathrm{hr}$. After centrifugation to remove cells a plasma sample was counted in a well-type Panax scintillation counter and, after the activity had decayed, the sodium content was determined. In freshwater experiments water samples were taken at the beginning and the end of the experiment for sodium determinations. Sodium loss from the fish, which contained up to $160 \mathrm{mmol}$, raised the sodium content of the 40-1 tanks, which initially contained only 8 or $10 \mathrm{mmol}$, during some experiments so that the specific activity of the bath declined. The influx was calculated as in McWilliams (1980) on the assumption that all the sodium in the fish was exchangable as a single compartment and that the fish contained $31.4 \mathrm{mmol} \mathrm{Na} / \mathrm{kg}$ in sea-water and $25 \mathrm{mmol} \mathrm{Na} / \mathrm{kg}$ when adapted to fresh water, see below. When the specific activity of the bath changed during the experiment it was assumed that the change was linear. Where possible the fish were allowed to settle down in the tank for an hour or two before the isotope was added. In order to expedite mixing the isotope was distributed widely over the surface of the tank.

Fish were transferred from sea-water to fresh water, whenever possible, by flushing the tank containing the fish with fresh water but this procedure required between 5 and 10 min to reduce the sodium content of the tank to below $0.5 \mathrm{mmol} \mathrm{Na} /$. Studies on the rate of sodium uptake and loss immediately following transfer from sea-water to fresh water were carried out by lifting the fish from the sea water tank, in a net, first to a large tank of fresh water for a minute to wash, then to the experimental tank in which the isotope had already been mixed.

Sodium efflux in sea-water was measured by injecting a known quantity of ${ }^{24} \mathrm{Na}$ into the peritoneum of a fish, whilst in the experimental tank, and measuring the activity of $250 \mathrm{ml}$ samples of the bath over the following $6 \mathrm{hr}$. If the quantity of ${ }^{24} \mathrm{Na}$ remaining in the fish at any two occasions $T_{1}$ and $T_{2}$ is $C_{1}$ and $C_{2}$, then

$$
K-\frac{1}{T_{1}-T_{2}} \operatorname{Ln} \frac{C_{1}}{C_{2}}
$$

After the first hour or so, during which time the sodium became distributed throughout the sodium space of the fish,
$K$ became almost constant. Most estimates were based on the interval between 2 and $5 \mathrm{hr}$ after injection.

Sodium taken up at the gills appears rapidly in the blood but equilibrates more slowly with the intracellular sodium in the white muscle which has a very limited blood supply. Estimates of fluxes based on changes in the specific activity of the blood will therefore not be exactly comparable with fluxes based on changes in the specific activity of the sodium in the whole body (Potts et al, 1970). To assess the magnitude of this discrepancy samples of white muscle were taken from six fishes $1 \mathrm{hr}$ after the beginning of the experiments. The mean specific activity of the whole muscle sodium, after 1 he was $67+13 \%$ that of the plasma.

The mean sodium content of the whole muscle was $12.6 \mathrm{mmol} / \mathrm{kg}$. The muscle tissue amounted to $80 \%$ of the weight of the fish and held $10.1 \mathrm{mM} / \mathrm{kg}$ of the total body sodium, assumed to be $31.4 \mathrm{mM} / \mathrm{kg}$. Alter $\mathrm{I} \mathrm{hr}$ the specific activity of the blood would be $10 \%$ higher that that of the total body sodium. Estimated fluxes, calculated from tate constants and an assumed valuc of $31.4 \mathrm{mM} \mathrm{Na} / \mathrm{kg}$ total body sodium, have been reduced by this amount for comparison with fluxes calculated from changes in the sodium contents of the baths

$\mathrm{Na}$ determinations were made by an EEL flame photometer and chloride determinations were made by a Radiometer $\mathrm{CM} 10 \mathrm{Chloride}$ meter using $20 \mu \mathrm{l}$ samples of plasma suitably diluted.

Prolactin was measured by radio-immune-assay, by Dr P. Prunet, using a highly specific radioimmunoassay. Hirano et al., 1985.

Water was acidified by the addition of dilute sulphuric acid, aluminium was added as $\mathrm{AlCl}_{3}$ and monomeric aluminium was assayed by the catechol violet method (Dougan and Wilson, 1974). When fish were present the concentration of monomeric aluminium initially fell very rapidly. Where practicable experimental tanks were pretreated with aluminium. At the beginning of an experiment the quantity of aluminium required to reach the experimental concentration was added, together with $100 \mu \mathrm{mol} \mathrm{Al} / \mathrm{kg}$ fish. After $15 \mathrm{~min}$ the aluminium concentration was measured and additional aluminium was added to bring the concentration back to the required level if necessary. This process was repeated about every half hour.

The individual variation between fish is considerable and so as far as possible fish were used as their own controls Individual fish were treated on the cycle: FW $2 \mathrm{hr}$, Acid water $2 \mathrm{hr}$. Acid and Al $2 \mathrm{hr}$. In a few cases the cycle was reversed.

\section{RESULTS}

\section{Salt balance in sea-water}

The mean rate of sodium exhange in four fish from Carnoustie was $12.6 / \mathrm{hr}$. A fifth fish which had been taken from fresh water but had been returned to sea-water for 10 days had a rate of sodium exchange of $7.8 \% \mathrm{hr}$ and has not been included.

The mean plasma sodium concentration of adult salmon in sea-water was $183 \pm 3 \mathrm{mml} \mathrm{Na} / 1$ plasma $(N=12)$.

\section{Transfer to fresh water}

Sodium uptake. As previously reported (Potts et al., 1985) sodium uptake attains normal freshwater levels immediately after transfer. Uptake follows Michaelis-Menten kinetics (Fig. 2) and a Lineweaver-Burk plot shows that $F_{\max }=2.40 \mathrm{mmol} / 1$ extracellular fluid $/ \mathrm{hr}$ and $K_{\mathrm{m}}=0.26 \mathrm{mmol} \mathrm{Na} / \mathrm{l}$. In the first hour after transfer to Almond river water containing $0.2 \mathrm{mmol} \mathrm{Na} / 1$ the rate of uptake 


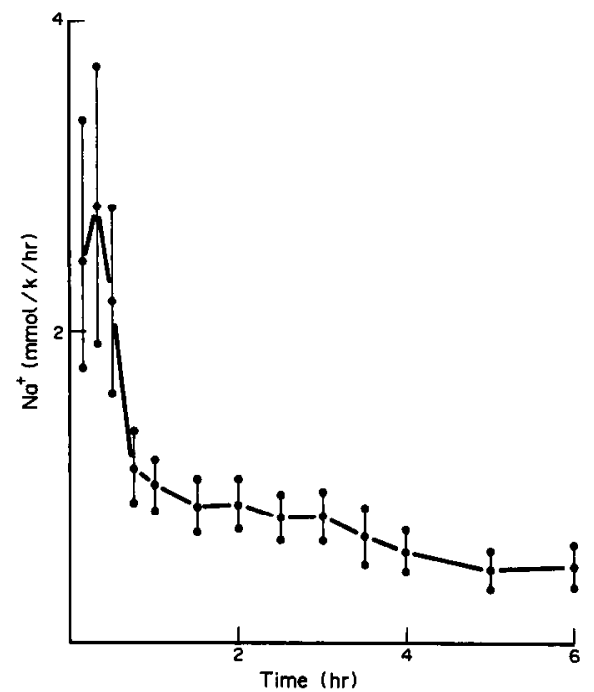

Fig. 2. The rate of net sodium loss ( $\mathrm{mmol} \mathrm{Na} / \mathrm{kg} / \mathrm{hr}$ ); $N=4$ $( \pm \mathrm{SE})$.

was $0.95 \mathrm{mmol} \mathrm{Na/l} \mathrm{ECF} \mathrm{hr}(N=17)$. This sodium uptake is equivalent to about $0.143 \mathrm{mmol} / \mathrm{kg} / \mathrm{hr}$, assuming an ECF volume equivalent to $15 \%$ of body weight (Talbot et al., 1986). In the shortest experiment, in which the fish was removed from sea-water and washed for only $2 \mathrm{~min}$ the rate of uptake during the succeeding $5 \mathrm{~min}$ was $1.91 \mathrm{mmol}$ $\mathrm{Na} / \mathrm{l} \mathrm{ECF}$ hr but the mean sodium concentration of the medium during the experiment was high (0.37 mmol Na/l).

\section{Sodium loss}

During the first few minutes following transfer from sea-water to fresh water, sodium losses remained high (Fig. 3). The rate of loss declined rapidly during the first hour and the fish were close to equilibrium after $24 \mathrm{hr}$, the mean net loss in three fish at this time being only $0.07 \mathrm{mmol} / \mathrm{kg} / \mathrm{hr}$ (Fig. 3). The cummulative salt loss reached $5.6 \mathrm{mmol} / \mathrm{kg}$ after $6 \mathrm{hr}$ (Fig. 3).

Blood concentrations were also measured on salmon kept in sea-water but subjected to the same

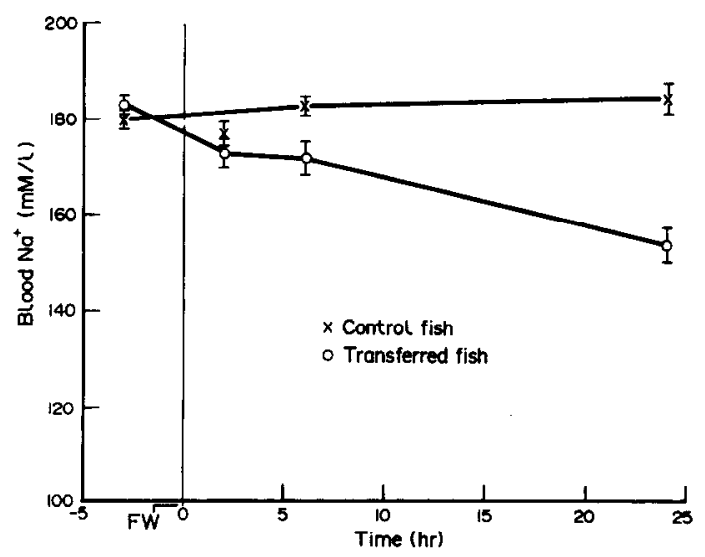

Fig. 3. Concentration of sodium in the plasma of salmon in sea-water and following transfer to fresh water at zero time; $N=6( \pm S E)$.

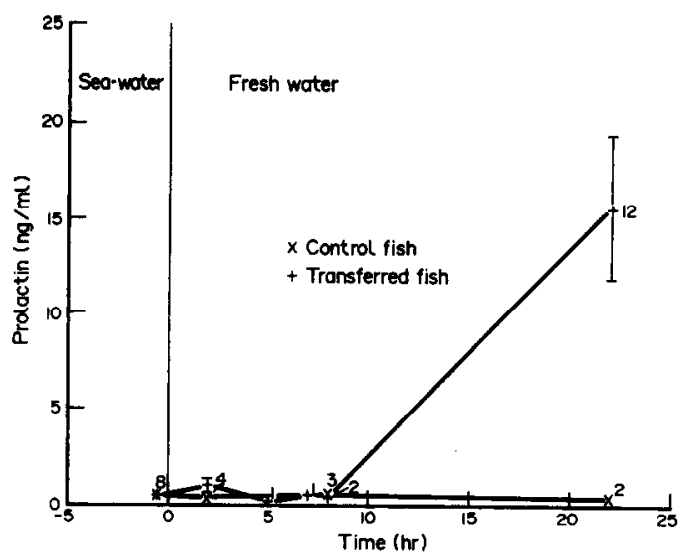

Fig. 4. Concentration of prolactin in salmon blood following transfer from sea-water to fresh water. *Sea water-controls.

cannulation and handling as the salmon which were transferred from sea water to fresh water. These fish showed only a slight elevation of blood concentration (Fig. 4).

\section{Sodium uptake in post-smolts}

The unusual ability of the adult salmon to take up sodium from fresh water at the rate found in fish fully adapted to fresh water, immediately after transfer from sea-water, raises the question of whether this is a feature of all salmon adapted to sea-water or whether it is a transitory feature of migrating salmon, which only develops as they approach their home rivers. To distinguish between these possibilities, rates of sodium uptake after transfer to fresh water were also measured in salmon which had smolted in the spring and had been subsequently confined to sea-water for 5 months. The rate of uptake was initially much lower in these fish but rose slowly over several days following transfer. However, they were unable to maintain blood concentrations as high as those of adult fish (Table 1).

\section{Weight}

Water influx must begin immediately following transfer to fresh water although urine production remains low for a day or more (Talbot et al., 1989). The adult salmon showed a marked tendency to gain weight during the first $24 \mathrm{hr}$ after transfer, the net gain being ca $6 \%$ after $8 \mathrm{hr}$ and $12 \%$ after $24 \mathrm{hr}$ (roughly equivalent to the urine deficit). Later, weight returned towards the sea-water level.

\section{Prolactin}

Prolactin levels are very low in the plasma of adult salmon in sea-water, $0.55 \pm 0.066 \mathrm{ng} / \mathrm{ml}$ $(N=8)$. Following transfer to fresh water the level does not rise significantly during the next $8 \mathrm{hr}$ but $22 \mathrm{hr}$ later it averages $16.4 \pm 3.8 \mathrm{ng} / \mathrm{ml}(N=6)$. Controls in sea-water subjected to the same sampling regime showed no significant change (Fig. 5).

\section{The effects of low pH on sodium balance}

In water of $\mathrm{pH} 5.0$ the rate of sodium uptake fell to $0.114 \pm 0.026 \mathrm{mmol} / 1 \mathrm{ECF} \mathrm{hr}$, but at $\mathrm{pH} 4.0$ it was 
Table 1. Sodium uptake in salmon ( $S$, salar) following transfer from sea-water to fresh water by post smolts

\begin{tabular}{lcccc}
\hline & $\begin{array}{c}\text { Uptake } \\
(\text { mmol/l ECF/hr) }\end{array}$ & $\begin{array}{c}\text { Uptake } \\
(\% \mathrm{Na} / \mathrm{hr})\end{array}$ & $\begin{array}{c}\text { Blood conc. } \\
(\mathrm{mmol} \mathrm{Na} / 1)\end{array}$ & $N$ \\
\hline lst hour & $0.30 \pm 0.06$ & $0.23 \pm 0.05$ & $130 \pm 2$ & 6 \\
$42 \mathrm{hr} \mathrm{FW}$ & $0.99 \pm 0.08$ & $0.96 \pm 0.12$ & $106 \pm 4$ & 6 \\
$72 \mathrm{hr}$ FW & $0.82 \pm 0.06$ & $1.02 \pm 0.07$ & $81 \pm 4$ & 3 \\
\hline
\end{tabular}

$F W=$ Freshwater.

similar (Table 3). However, when the fish were used as their own controls the rate at pH 5.0 was only $9 \%$ of that in neutral water $(N=3)$ while at $\mathrm{pH} 4.0$ the rate was only $23 \%$ of that at $\mathrm{pH} 5.0(N=3) .4+$ parr showed a similar fall in sodium uptake (Table 3 ). These rates of uptake at low $\mathrm{pH}$ will be slightly enhanced as the reduction in uptake leads to a rise in the ambient concentration of sodium by about $0.05 \mathrm{mmol}$ after $2 \mathrm{hr}$ when a $3 \mathrm{~kg}$ fish is confined in a 40-1 tank.

\section{The effects of aluminium ions on sodium balance}

The rate of uptake is low in acid conditions so that any further reductions in uptake following the addition of aluminium ions were small. Even in $50 \mu \mathrm{mol} \mathrm{Al} / 1$ some sodium uptake was detected although this may have taken place during the earlier part of the $2 \mathrm{hr}$ treatment period.

Sodium uptake remained low for at least $24 \mathrm{hr}$ after treatment with aluminium even after the fish had been well washed in running river water. After $4 \mathrm{hr}$ of treatment with $20 \mu \mathrm{mol} \mathrm{Al} / \mathrm{l}$ at $\mathrm{pH} 5.0$ the rate of uptake by $4+$ parr in fresh river water at $\mathrm{pH} 6.9$ during the first hour after return to normal water was only $0.0263 \pm 0.010 \mathrm{mmol} / 1 \mathrm{ECF} / \mathrm{hr} \quad(N=6)$ and even $24 \mathrm{hr}$ later it was still only $0.52 \pm 0.07(N=6)$, about half the rate of the control parr. The rates of uptake in two salmon $24 \mathrm{hr}$ after similar treatment were 0.47 and $0.58 \mathrm{mmol} \mathrm{Na} / \mathrm{l} \mathrm{ECF} / \mathrm{hr}$-about half the normal rate. None of the salmon or parr survived for more than 3 days after Al treatment.

Sodium loss in the presence of $20 \mu \mathrm{mol} \mathrm{Al} / 1$ averaged about one quarter higher than the rate in aluminium-free water at the same $\mathrm{pH}$ but the results were very variable and the difference was not significant at the 5\% level (Table 2).

Sodium balance in two fish which were transferred directly from sea-water to acid water of $\mathrm{pH} 5.0$ containing $20 \mu \mathrm{mol} \mathrm{Al} / 1$ were not significantly different from fish transferred directly from sea-water to aluminium-free acid water.

As the salmon become restless in small tanks in adverse conditions experiments in acid and aluminium ions were usually limited to 4 or $6 \mathrm{hr}$ in length, during which time the blood concentrations fell by only a few mmol// EFC. Following treatment with aluminium at 10,20 and $50 \mu \mathrm{mol} / \mathrm{l}$ the concentrations of plasma sodium continued to fall after return to neutral fresh water. Blood concentrations of 112 and $128 \mathrm{nmol} \mathrm{Na} / 1$ were recorded in two salmon, 2 days after $6 \mathrm{hr}$ in $20 \mu \mathrm{mol} \mathrm{Al} / 1$ and the only two parr which survived for $24 \mathrm{hr}$ after $6 \mathrm{hr}$ in $40 \mu \mathrm{mol}$ $\mathrm{Al} / 1$, had blood concentrations of 120 and $124 \mathrm{mmol}$ $\mathrm{Na} / \mathrm{l}$. Three parr which survived for $24 \mathrm{hr}$ after $6 \mathrm{hr}$ in $20 \mu \mathrm{M} \mathrm{Al} / 1$ had concentrations of 117,125 and $143 \mathrm{mmol} \mathrm{Na} / \mathrm{l}$.

\section{DISCUSSION}

Salmon do not usually move directly from seawater to fresh water but either move up an estuary over a period of time (Hawkins and Smith, 1986) or, oscillate several times between the two waters. An infinite variety of programmes of transfer might be devised, but all would make measurements of salt uptake and loss and their interpretation more difficult. For this reason direct transfer was preferred.

The ability of adult salmon to take up sodium at the full rate immediately following entry into fresh water must make a useful contribution to maintaining sodium balance, reducing the net fall of plasma sodium during the first day by $21 \mathrm{mmol} / \mathrm{l}$. Evans (1982) has shown that a little sodium is exchanged for hydrogen ions even in marine fish, but it would be wasteful to maintain sodium uptake at a high rate throughout its life at sea. It seems likely that the pump develops as they approach fresh water and that adult salmon are pre-adapted to fresh water while still at sea, as the smolt is pre-adapted to sea water while still in the river. Post-smolts had a very much lower rate of uptake and only reach the adult level after 3 days.

Because the pump saturates at a relatively low external concentration the rate of sodium uptake, even in sea-water, would reach only $2.3 \mathrm{mM} \mathrm{Na} / 1$ ECF or about $1.2 \%$ of total plasma sodium $/ \mathrm{hr}$, a small part of the sea-water exchange of $c a 12 \% / \mathrm{hr}$.

There is little information on whole body compositions of adult salmon. Shearer (1984) found that whole rainbow trout in fresh water contained on average $58 \mathrm{mmol} \mathrm{Na} / \mathrm{kg}$ wet weight. Salmon smolts contained only $30.3 \mathrm{mmol} \mathrm{Na} / \mathrm{kg}$ wet weight when adapted to fresh water but contained $44.8 \mathrm{mmol} / \mathrm{kg}$ in sea-water Potts et al., 1970. Using neutron activation analyses. Talbot et al. (1986) found that adult salmon in sea-water contained only $27.4 \mathrm{mmol} \mathrm{Na} / \mathrm{kg}$ and a

Table 2. Sodium uptake by $4+$ parr and by adult salmon (S. salar) at various pH at $12^{\circ} \mathrm{C}$

\begin{tabular}{lcccc}
\hline FW adaptation & $\begin{array}{c}\text { Treatment } \\
(\mathrm{pH} \mathrm{6})\end{array}$ & $\begin{array}{c}\text { Al treatment } \\
(6 \mathrm{hr})\end{array}$ & $\begin{array}{c}\mathrm{Na} \mathrm{loss} \\
\text { mmol kg/hr }\end{array}$ & \\
\hline 1 day, pH 6.5-7.0 & $6.5-7.0$ & 0 & $0.075 \pm 0.04$ & $N=3$ \\
1 day, pH 6.5-7.0 & 5.0 & 0 & $0.136 \pm 0.018$ & $N=4$ \\
$3-5$ days & 5.0 & 0 & $0.237 \pm 0.067$ & $N=4$ \\
3 & 5.0 & $20 \mu \mathrm{M} \mathrm{Al}$ & $0.373 \pm 0.116$ & $N=7$ \\
1 & 4.4 & 0 & $0.294 \pm 0.11$ & $N=4$ \\
\hline
\end{tabular}


Table 3. Net sodium loss from $S$. salar adults

\begin{tabular}{lccc}
\hline \multicolumn{3}{c}{$\mathrm{mmol} \mathrm{Na} / \mathrm{l} \mathrm{ECF} / \mathrm{hr}$} \\
\cline { 2 - 4 } & $\mathrm{pH} 7.0$ & $\mathrm{pH} 5.0$ & $\mathrm{pH} 4.0$ \\
\hline Adult & $0.903 \pm 0.083$ & $0.114 \pm 0.026$ & $0.131 \pm 0.037$ \\
& $N=3$ & $N=6$ & $N=10$ \\
$4+$ parr & $1.38 \pm 0.24$ & $0.123 \pm 0.029$ & $0.075 \pm 0.020$ \\
& $N=4$ & $N=7$ & $N=10$ \\
\hline
\end{tabular}

total water content of only $601 \mathrm{~g} / \mathrm{kg}$. The low water and sodium content was associated with the very high lipid content of returning adults.

Net sodium fluxes were measured from changes in the sodium content of the medium, sodium influxes from the rate of appearance of ${ }^{24} \mathrm{Na}$ in the plasma. It is difficult to relate the two methods exactly. An adult fish contains about $600 \mathrm{~g}$ water $/ \mathrm{kg}$, of which about $150 \mathrm{~g}$ are extracellular. Talbot et al. (1986). If the extracellular $\mathrm{Na}$ is $183 \mathrm{mmol} / 1$ in sea-water and $154 \mathrm{mmol} / \mathrm{l}$ in fresh water and the intracellular concentrations are 8 and $5 \mathrm{mmol} / 1$, respectively, then the total sodium content would be 31.4 and $25.0 \mathrm{mmol} / \mathrm{kg}$, respectively, a difference of $6.4 \mathrm{mmol} / \mathrm{kg}$. This is slightly larger than the observed net loss of $5.6 \mathrm{mmol} / \mathrm{kg}$ during the first $6 \mathrm{hr}$ but the fish were still out of equilibrium $24 \mathrm{hr}$ later.

In sea-water the rate of sodium efflux is $3.8 \mathrm{mmol} / \mathrm{kg} / \mathrm{hr}$. After $6 \mathrm{hr}$ and a cumulative net loss of $5.6 \mathrm{mmol} \mathrm{Na} / \mathrm{kg}$ the rate of net loss has fallen to $0.63 \pm 0.045 \mathrm{mmol} / \mathrm{kg} / \mathrm{hr}$, and after $24 \mathrm{hr}$ it is only $0.07 \mathrm{mmol} / \mathrm{kg} / \mathrm{hr}$ (Fig. 3). The physical bases of this decline must include the shutting down of the chloride pump and changes in the structure of the tight junctions between the mitochondrial rich cells in the gill epithelium. $5.6 \mathrm{mmol} / \mathrm{kg}$ amounts to $18 \%$ of the total body sodium but during this time the average blood concentration falls from 183 to $172 \mathrm{mmol} / \mathrm{l}$ or only $6 \%$. The blood concentration may be maintained by the transfer of sodium from tissues to plasma and by a decrease in the extracellular volume due to an increase in cell volume as the osmotic pressure falls.

The levels of prolactin in the sea-water adapted salmon are very low $(0.55 \mathrm{ng} / \mathrm{ml})$. In comparison the plasma of the Steelhead, Salmo gairdneri, adapted to sea-water, contained $3-5 \mathrm{ng} / \mathrm{ml}$, but this rose to $c a$ $14 \mathrm{ng} / \mathrm{ml}$ in fish adapted to fresh water, while in Oreochromis mossambica the levels rose from 8 to $55 \mathrm{ng}$ (Nicoll et al., 1981). On transfer to fresh water the level in salmon plasma had not risen significantly after $8 \mathrm{hr}$ ) but $22 \mathrm{hr}$ later the level had risen 30 -fold to $16.4 \pm 3.8 \mathrm{ng} / \mathrm{ml}$ (Fig. 5).
In view of the low levels of prolactin in the sea-water and the slowness of the response in fresh water it seems unlikely that prolactin can be involved in the ability of the salmon to take up sodium immediately on entry to fresh water or in the rapid reduction in salt loss which takes place during the first hour in fresh water. Prolactin is involved in the maintenance of osmoregulatory homeostasis in fresh water by decreasing salt loss (Potts and Evans, 1966). The mechanism of prolactin release is uncertain as the perfusion experiment shows that the osmotic pressure of the plasma is not an important factor in the release (Gonnet et al., 1988).

Sodium efflux in a fish fully adapted to fresh-water and in sodium balance is $0.14 \mathrm{mmol} / \mathrm{kg} / \mathrm{hr}$. One day after transfer from sea-water the net loss was $0.136 \mathrm{mmol} / \mathrm{kg} / \mathrm{hr}$ at $\mathrm{pH} 5.0$ while after $3-5$ days the net loss at $\mathrm{pH} 5.0$ was $0.24 \mathrm{mmol} / \mathrm{kg} / \mathrm{hr}$, increasing to $0.29 \mathrm{mmol} / \mathrm{kg} / \mathrm{hr}$ at $\mathrm{pH} 4.4$ (Table 3 ). This suggests that loss is increased in salmon at low $\mathrm{pH}$ as in brown trout (McWilliams and Potts, 1978).

The results reported here suggest that the deaths of adult migrating salmon reported in the Duddon and Esk in 1983 were due mainly to the inhibition of the sodium uptake system by the low $\mathrm{pH}$ and aluminium, the inhibition being caused by the aluminium continuing to reduce uptake for at least $24 \mathrm{hr}$ afterwards.

There is some inconsistency in the reported effects of low $\mathrm{pH}$ and aluminium ions on sodium uptake in fish. Many authors have found that low $\mathrm{pH}$, even in the absence of aluminium ions, will inhibit sodium uptake in fishes, e.g. brook trout, $S$. salvelinus (Paker and Dunson, 1970); sailfin molly, Poecilia latipinna (Evans, 1975); rainbow trout, $S$. gairdneri (Kerstetter et al., 1970); brown trout, S. trutta (McWilliams and Fotts, 1978); goldfish, Carassius auratus (Maetz, 1973) as well as several invertebrates such as the crayfish, Austropotamobius (Shaw, 1960). In contrast Dalziel (1986) found no effect of $\mathrm{pH}$ on sodium influx in the brown trout except in the presence of aluminium ions, where as little as 1 or $2 \mu \mathrm{mol} \mathrm{Al} / 1$ had an appreciable effect. Some of the discrepancy between Dalziel's results and those of other workers

Table 4. Estimated sodium balance in adult $S$, salar following transfer from sea-water to neutral fresh water, acidic fresh water and acidic fresh water containing $20 \mu-\mathrm{M} \mathrm{Al} / 1$

\begin{tabular}{|c|c|c|c|c|}
\hline & $\begin{array}{l}\text { Neutral water, } \\
24 \mathrm{hr}\end{array}$ & $\begin{array}{c}\text { Water pH 5, } \\
24 \mathrm{hr}\end{array}$ & $\begin{array}{c}\text { Water pH } 5 \text { containing } \\
20 \mu \mathrm{mol} \mathrm{Al} / 1,24 \mathrm{hr}\end{array}$ & $\begin{array}{c}\text { Neutral water for } 24 \mathrm{hr} \\
\text { after acid and } \\
\text { aluminium treatment }\end{array}$ \\
\hline \multicolumn{5}{|l|}{ Total body $\mathrm{Na}$ at beginning } \\
\hline of period & 31.4 & 31.4 & 31.4 & 21.9 \\
\hline Loss $\mathrm{mM} / \mathrm{kg}$ in $24 \mathrm{hr}$ & 9.8 & 9.8 & 9.8 & 3.4 \\
\hline Uptake, $\mathrm{mM} / \mathrm{kg}$ in $24 \mathrm{hr}$ & 3.4 & 0.3 & 0.3 & 0.8 \\
\hline $\begin{array}{l}\text { Total body } \mathrm{Na} \text { at end of period } \\
\mathrm{mM} / \mathrm{kg}\end{array}$ & 25.0 & 21.9 & 21.9 & 19.3 \\
\hline $\begin{array}{l}\text { Blood conc. at beginning } \\
\text { of period } \mathrm{mM} \mathrm{Na} / 1\end{array}$ & 183 & 183 & 183 & 140 \\
\hline $\begin{array}{l}\text { Blood conc. if fall } \alpha \text { to } \\
\text { initial fall } \mathrm{mM} \mathrm{Na/1}\end{array}$ & 154 & 140 & 140 & 128 \\
\hline
\end{tabular}


may have been caused by the unsuspected presence of traces of aluminium in water. The volumes of water required with experiments with adult salmon are so large that it is impracticable to prepare synthetic solutions from deionized water but no aluminium was detected $(<1.0 \mu \mathrm{mol} / \mathrm{l})$ in the water; nevertheless, a marked reduction of sodium uptake was observed at low $\mathrm{pH}$. It may be significant that in these experiments uptake was measured during the several hours immediately following acidification. Some of the apparent discrepancy between different experiments may arise from the adaptation of the fish to acid conditions.

It is possible to construct a sodium balance sheet for adult salmon migrating up an acid river directly from the sea or meeting an acid spate when already adapted to fresh water (Table 4). In neutral river water the gross loss will be about $9.8 \mathrm{mmol} \mathrm{Na} / \mathrm{kg}$ during the first $24 \mathrm{hr}$ but the fish will replace about $3.4 \mathrm{mmol} \mathrm{Na} / \mathrm{kg}$. As a result the total body sodium will fall by $20 \%$ from 31.4 to $25 \mathrm{mmol} \mathrm{Na} / \mathrm{kg}$ while the blood concentration will have fallen by about $16 \%$ from 183 to about $154 \mathrm{mmol} \mathrm{Na} / 1$ plasma (Table 4).

If the $\mathrm{pH}$ remained below 5.5 for $24 \mathrm{hr}$ the net loss would increase to $9.5 \mathrm{mmol} / \mathrm{kg}$. The blood sodium is not directly proportional to total body sodium but if a fall of $6.4 \mathrm{mmol} \mathrm{Na} / \mathrm{kg}$ total body sodium corresponds to a fall of $29 \mathrm{mmol} / 1$ blood (183-154 mmol $\mathrm{Na} / \mathrm{l}$ ) then the blood sodium would fall to only $140 \mathrm{mmol} / 1$. Leivestad and Muniz (1976) found that some brown trout, $S$. trutta, began to die when the blood concentrations fell below $150 \mathrm{mmol}$ $\mathrm{Na} / \mathrm{l}$ and mortality was great at $120 \mathrm{mmol} \mathrm{Na} / \mathrm{l}$, although some individuals were still alive with blood sodium as low as $90 \mathrm{mM} \mathrm{Na} / \mathrm{l}$.

After only $4 \mathrm{hr}$ in $20 \mu \mathrm{mol} \mathrm{Al} / 1$, the probable level reached in the Esk in 1983, sodium uptake in the salmon is still only half the normal rate $24 \mathrm{hr}$ after the fish have been returned to neutral, aluminium-free water. If the recovery of sodium uptake is linear then the uptake during the $24 \mathrm{hr}$ following return to neutral water would be only $0.8 \mathrm{mmol} / \mathrm{kg}$. While the fall in blood concentration might reduce sodium loss to some extent aluminium appcars to increase loss (Table 3), and Dalziel (1986) found that in the brown trout efflux increased at $\mathrm{pH} 5.4$ as aluminium rose. It is therefore likely that gross loss would at least be maintained (Table 4). If the $\mathrm{pH}$ returned to neutrality after $24 \mathrm{hr}$ the sodium loss during the following day would be $2.6 \mathrm{mmol} / \mathrm{kg}$. The total loss would therefore be $9.5+2.6$ or $12.1 \mathrm{mmol} / \mathrm{kg}$, corresponding to a plasma concentration of $128 \mathrm{mmol} \mathrm{Na} / \mathrm{l}$ (Table 4).

Several of the fish which were treated with aluminium died overnight. The plasma concentrations which were recorded in survivors were consistent with these calculations: 112 and $128 \mathrm{mmol} \mathrm{Na} / 1$ in two salmon and $120,124,117,125$ and 143 in five $4+$ parr.

The effect of two short $8 \mathrm{hr}$ acid episodes separated by 2 days might be as follows. During the total of $16 \mathrm{hr}$ at low $\mathrm{pH}$ and high aluminium, sodium uptake would be very small and the net loss would be $2.4 \mathrm{mmol}$. During each of the subsequent $24 \mathrm{hr}$ net loss would be about $2.4 \mathrm{mmol} / \mathrm{kg}$ making a total net loss of $7 \mathrm{mmol} / \mathrm{kg}$. A net loss of $7 \mathrm{mmol}$ would lower the blood concentration about $32 \mathrm{mmol} / 1$ below normal, taking it well into the lethal range. It seems likely that two successive episodes would be more damaging than a single episode of the same total length if the salmon do not have time to recover in between. The effects of aluminium and acid on fish already in the river and fully adapted to fresh water will be similar (Table 4).

Even lower concentrations of aluminium are effective in suppressing uptake in the trout (Dalziel, 1986) but more work is required on the rate of recovery of sodium uptake from lower concentrations.

Acknowledgements-The authors would like to express their gratitude to $\mathrm{M}$. Miles, S. Keay and J. Muir of the Almondbank Hatchery, without whose help this work could not have done. Also, we would like to thank Mr E. Duncan of Carnoustie and Mr. I. Mitchell of Tay Salmon Fisheries, Perth for their help in procuring fish. This work was funded in part by the Surface Water Acidification Programme of the Royal Society, the Royal Swedish Academy of Sciences, the Norwegian Academy of Science and Letters and by Natural Environment Research Council, Grant No. GR3/6218.

\section{REFERENCES}

Crawshaw D. (1984) Effect of acid rain on chemistry of streams in Cumbria. North West Water Report T.S.N. $84 / 3$.

Dalziel T. (1986) Sodium regulation in $S$. trutta in the presence of acid and aluminium. Ph.D. thesis, University of Nottingham.

Dougan W. K. and Wilson A. L. (1974) The absorptiometric determination of aluminium in water. A comparison of some chromogenic reagents and the development of an improved method. Analyst 99, 413-430.

Evans D. H. (1975) The effects of various external cations and sodium transport inhibitors on sodium uptake by the sailfin Mally, Poecilia latipinna, acclimated to sea water. J. comp. Physiol. 96, 111-115.

Evans D. H. (1982) Mechanisms of acid extrusion by two marine fishes: the teleost Opsanus beta, and the elasmobranch, Squalus acanthius. J. exp. Biol. 97, 289-299.

Girard J. P. and Payan P. (1980) Ionic exchange through respiratory and chloride cells in freshwater and seawater adapted teleosteans in adrenergic control. Am. J. Physiol. 238, R260-268.

Gonnet F., Prunet P., Tunon M. C., Dubourg P., Kah O and Vaudry F. (1988) Effect of osmotic pressure on prolactin release in rainbow trout: in vitro studies. Gen. comp. Endocrinol. 69, 252-261.

Hawkins A. D. and Smith G. W. (1986) radio-tracking observation on Atlantic salmon ascending the Aberdeenshire Dee. Scottish Fisheries Research Report 36, 1-24.

Hirano T., Prunet P., Kawauchi H., Takahashi A., Ogasawara T., Kubota J., Nichioka R. S., Bern H. A., Takada K. and Ishu S. (1985) Development and validation of a salmon Prolactin Radioimmunoassay. Gen. comp. Endocrinol. 59, 266-276.

Kerstetter T. H., Kirschner L. B. and Rafuse D. D. (1970) On the mechanisms of sodium ion transport by irrigated gills of rainbow trout (Salmo gairdneri). J. gen. Physiol. 56, 342-359.

Leivestad H. and Muniz I. P. (1976) Fish kill at low pH in a Norwegian river. Nature 259, 391-392.

Maetz J. (1973) $\mathrm{Na}^{+} / \mathrm{NH}_{4}^{+}, \mathrm{Na}^{+} / \mathrm{H}^{+}$exchanges and $\mathrm{NH}_{3}$ movement across the gill of Caraussius auratus. J. exp. Biol. 58, 255-275. 
McWilliams P. G. (1980) Acclimation to an acid medium in the brown trout Salmo trutta. J. exp. Biol. 88, 269-280. McWilliams P. G. and Potts W. T. W. (1978) The effects of $\mathrm{pH}$ and calcium concentration on the gill potentials in the brown trout Salmo trutta. J. comp. Physiol. 126, 277-286.

Nicoll C. S., Wilson S. W., Nishioka R. and Bern H. A. (1981) Blood and pituitary prolactin levels in tilapia, Sarotherodon mossambicus from different salinities. Gen. comp. Endocrinal. 44, 365-373.

Paker R. K. and Dunson W. A. (1970) Effects of low environmental $\mathrm{pH}$ on blood $\mathrm{pH}$ and sodium balance of brook trout. J. exp. Zool. 174, 65-72.

Potts W. T. W. and Evans D. H. (1966) The effects of hypophysectomy and bovine prolactin on salt fluxes in fresh-water-adapted, Fundulus heteroclitus. Biol. bull. Woods Hole. 131, 362-368.

Potts W. T. W., Foster M. A. and Stather J. W. (1970) Salt and water balance in salmon smolts. J. exp. Biol. 52, 553-564.

Potts W. T. W., Talbot C. and Eddy F. B. (1985) Sodium balance in fresh-run Atlantic salmon. $J$. exp. Biol. 118, 455-460.
Prunet P., Boeuf G. and Houdebine L. M. (1985) Plasma and pituitary prolactin levels in rainbow trout during adaptation to different salinities. $J$. exp. Zool. 235, 187-196.

Shaw J. (1960) The absorption of sodium ions by the crayfish, Astacus pallipes Lereboullet. II. J. exp. Biol. 37, 548-556.

Shearer K. D. (1984) Changes in elemental composition in hatchery reared trout, Salmo gairdneri, associated with growth and reproduction. Can. J. Fish Aquatic. Sci. 41, $1592-1600$.

Smith C. S. and Bell G. R. (1964) A technique for prolonged blood sampling in free swimming salmon. J. Fish. Res. Bd. Can. 21, 711-717.

Talbot C., Eddy F. B., Potts W. T. W. and Primmett D. R. N. (1989) Renal function in migrating adult Atlantic salmon Salmo salar, L. Comp. Biochem. Physiol. 92A, 241-245. Talbot C., Preston T. and East B. W. (1986) Body composition of Atlantic salmon (Salmo salar L.) studied by neutron activation analysis. Comp. Biochem. Physiol. 85A, 445-450. 